\title{
STRATEGIES FOR MAKING MANAGEMENT DECISIONS IN INFORMATION AND ANALYTICAL ACTIVITY
}

\author{
Olha Danylyuk, Lyudmyla Petryshyn
}

The aim of the study is to substantiate and analyze the strategy of managerial decision-making in information and analytical activities, to specify the main aspects of analytics for decision-making.

Strategies for making managerial decisions in information and analytical activities are substantiated. The relevance of the use of information-analytical research is determined. The main aspects of analytics for decision making are analyzed, as well as the ranging of classes according to the degree of intelligence and complexity of tasks is taken into account. The peculiarities of completeness and reliability of information for information-analytical research are revealed. It is determined, that information analytics is a component of management.

The regional management analytics is analyzed, as a result of which it is proposed the scheme of regional management with the use of information and analytical support is offered. The basic principles of design are offered. It is proved, that the management system requires modern analytical support, performed according to the requirements of science, the latest methodologies, including information and analytical activities. Problems and negative sides in the process of information-analytical activity in the system of regional management are determined. It is noted, that information and analytical support helps to achieve the best results, and the effectiveness of activities in any field depends on the management system.

The obtained research results will allow will improve planning, organization and coordination of managerial decisionmaking and will help to form a significant information capital for making relevant management decisions at all hierarchical levels of management

Keywords: strategy, information, analytics, management, research, decision, analysis, algorithm, information analytics

(C) The Author(s) 2021

This is an open access article under the Creative Commons CC BY license hydrate

How to cite:

Danylyuk, O., Petryshyn, L. (2021). Strategies for making management decisions in information and analytical activity. ScienceRise: Pedagogical Education, 4 (43), 26-30. doi: http://doi.org/10.15587/2519-4984.2021.238041

\section{Introduction}

The information paradigm of modern society is based on accumulation of necessary information for its processing and use. Therefore, information has a special place in modern social and information development. Thus, it is possible to improve information that has become a universal category, which comes as a key component of innovative development and is a certain information resource. An information resource in information activity is a set of documents of certain categories that form common goals and form an information society, in which public relations in various spheres of activity take place on the basis of wide use of information computer technologies that can ever attract, distribute and use information and knowledge.

Today, there is an opportunity for quick awareness of everyone, in particular through such means as a personal computer and the Internet, which provides the creation of an information society with a global information infrastructure.

Scientific and technological progress ensures the constant growth of needs and demand for new information services. In addition, the development of new supertechnologies contributes to the emergence of new terms, definitions, categories. This is especially true in the field of information, which is developing rapidly, becoming a social phenomenon and is of great importance to humanity.

All public relations, which are based on the use of information, should be based on the use of modern information and communication technologies in combination with analytical activities. Analytical activity today is scientific, professional, which includes intellectual potential and is the basis of the management system. As a professional activity, it solves problems in all sectors of the economy. The purpose of analytical activities is to provide a set of raw data clear content. In the presence of quantitative and qualitative data, find an interpretation that reflects the raw data and turn them into the result of a meaningful presentation of events.

Problems are solved through decision-making (management decisions), where the effectiveness of the decision depends on the quality and analysis. At the same time, the management system requires modern analytical support, performed according to the requirements of science, the latest methodologies, including information and analytical activities.

The topic of information and analytical research strategy in management is relevant. Just as modern socie- 
ty requires business leaders to make quick and correct decisions, which accompanies the use of systematic, reliable and complete information. To do this, modern information and analytical tools should be used to search, analyze and synthesize information.

\section{Literary review}

An analysis of recent research and publications, devoted to the study and research of informationanalytical activities, has shown that many scientists have dealt with these issues. In their works have they repeatedly focused on the use of information and analytical activities in the process of making managerial decisions.

A significant contribution to the study of information and analytical activities was made by G. Silkova [1], who noted that information and analytical activities are an important component of the process of making effective management decisions, which significantly expanded the horizons of this area.

Investigating the work of information-analytical departments L. Filipov and I. Zakharov paid great attention to information systems in the new electronic communication environment [2].

A researcher V. Dobrovolska takes the position that in the process of making management decisions at information and analytical activities, one should systematically use computer tools for information and analytical support of management [3].

A significant contribution to the study of modern problems of information and analytical activities was made by $\mathrm{O}$. Kobelev, who analyzed in detail the activities of information and analytical centers and singled out information analytics as an important component of management decision making [4].

The works of foreign scientists are especially full of information, where such scientific schools have a rational approach to information and analytical activities. Among them, a significant place is occupied by the works of T. Andersen, who devoted his work to the strategies of information and analytical management [5]. $\mathrm{T}$. Bedford made a significant contribution to the information support of the practical component of management, using analysis, synthesis of information and various methods of information-analytical activities, because information is the subject, means and product of management [6].

Also significant is the work of a researcher A. Griffin, who in his research worked on management strategies and decision-making, and specified that information and analytical work provides stages of identifying problems of management system and their analysis, as well as preparation of management decisions, monitoring its implementation and assessment of its practical realization [7].

The issue of information and analytical activities is constantly improved by new researches of modern scientists, using the latest technologies and tools. Therefore, the topic of the strategy of information-analytical research in management is relevant. Just as modern society requires business leaders to make quick and correct decisions, which accompanies the use of systematic, reliable and complete information. To do this, modern information and analytical tools should be used to search, analyze and synthesize information.

\section{Research aim and tasks}

The aim of the study is to substantiate and analyze the strategy of managerial decision-making in information and analytical activities, to specify the main aspects of analytics for decision-making.

To achieve this goal, the following tasks were set:

1. To specify the main management functions.

2. To analyze information analytics as a component of management.

3. To substantiate regional management analytics.

\section{Materials and methods}

The application of general scientific methods: analysis, synthesis, induction and deduction, generalization, logical method allows to determine the role of information-analytical activity in the process of making managerial decisions.

In our study, we use the most important general scientific methods of analysis and synthesis, which are closely related, interact with each other, where (from Greek, analysis - disassembly, dismemberment; synthesis - connection) [7]. Analysis is the imaginary or real decomposition of whole objects into their constituent elements, their further study. This paper analyzes information analytics as a component of management. Synthesis is the separation of a rational grain from a large amount of information, and contains the full saturation of information, completeness, flexibility, reliability of data.

Methods of induction and deduction are also extremely important. In this paper, the methods of induction are used to study primary sources on our subject, and the method of deduction is used to use both our own and other people's material.

The method of generalization is also used - where the general features and properties of information analytics are fixed and the transition from single to general, from less general to more general is carried out.

The logical method as a means of mental activity of people (means of thinking) is used in the process of making quality and correct decisions.

\section{Research results and their discussion}

1. The main management functions

The main functions of management include the need to make decisions. The decision-making process in the management system is an information process. The decision is a set of information, specially collected, analyzed and processed by the subject of management [1].

An important factor in successful activity in the modern information society is the use of completeness of information. Which must be reliable and relevant. And also modern methods of information gathering, analysis, synthesis and professional provision must be used. Today there is a differentiation of demand for all types of information that is an urgent task in the field of management.

The management process is a complex process that includes managed and managing subsystems. Information interaction is an interaction of an object and a subject of management. The more fully informed a manager and the more able to make analytical management decisions, the more detailed his/her information, the more professional decisions as a result. 
Analyzing different types of management activities can identify tasks and their performers. According to the degree of complexity, tasks can be divided into: simple tasks; more complex tasks; poorly structured tasks; task of decision-making in the conditions of counteraction or conflict; the most difficult decision-making tasks [3].

2. Analysis of management information analytics.

Management information analytics combines a decision-making process that uses a system of accumulation, processing and synthesis of reliable information. And the following levels of information and analytical management are used: external and internal. The external include afferent synthesis. And the internal include efferent synthesis.

Important are the conditions of management information support, namely: specialization of training of general specialists; determining the specifics of information services. Information in terms of information management can change its main function to the work of the organization. Thus, information support of management and business can include such components, as search of ideas, hypotheses, decisions; identification of problems, trends, alternatives, conflicts and emergencies; assessment of complex objects; information modeling of problems; formation of a system of criteria and assessments; introduction of scientific and technical achievements and best practices of competing organizations; collection and analysis of data on counterparties $[1,8,9]$.

Information and analytical support in the process of making management decisions helps to achieve the best results, and the effectiveness of the activity depends on the management system.

The concept of "management" in scientific researches is interpreted as planning, organization and coordination of operations between team members, which are aimed at achieving the goal. Management is the basis of rational activity of an organization. At the same time, it is one of the main stages of the labor process, the main purpose of which is to achieve general and specific functions. The effectiveness of management depends on qualified professionals, organizational and managerial structure, and the availability of leadership qualities of a manager.

The optimal management functions include purposefulness, motivation of work, management function, decision making [1]. The implementation of functions is carried out at the following stages of management: in the planning process; organization of the labor process; information and analytical support; at the control stage.

Information is a unifying element in management decisions. In the management process, a manager as a generator of ideas must have a range of specific qualities and features. Features of management include such functions as "energy concentration", i.e. creating an atmosphere of enthusiasm and desire to work. Managers need to generate much more energy in order for employees to work hard; strive for collective professionalism, for "group management"; to systematize document circulation in the management process [1].

3. Regional management analytics.

One of the important places of management is occupied by regional management analytics. The concept of "region" is a territory, which is characterized by a commonality of different conditions. The following criteria of regions are distinguished: um, high;

- by level of economic development: weak, medi-

- by pace of economic development: depressed, progressive;

- depending on economic growth indicators: negative, positive, zero;

- by type of territorial structure: nodal, homogeneous;

- by population density coefficient;

- by demographic indicators: life expectancy, mortality rate, birth rate, age-statistical structure;

- by nature and coefficient of industrial specialization [1]

The criteria for classifying regions are directly related to the infrastructure of a region, which can be production, energy, transport, economic, social, information. All infrastructures are closely interconnected, interdependent and interoperable.

The effectiveness of information support in a region depends on the rational use of information reversal, because the creation of the information infrastructure will ensure effective management of the region.

The subject of establishing information relations is regional authorities. Leading analysts, experts and specialists of regional analytical services should form a comprehensive technological base of modern analytical services.

It is important at the present stage of development of the information process to create a scheme of regional management, which is shown in Fig. 1.

The trial and error method is used to implement information complexes.

Having analyzed the principles of designing analytical and information services in the regions of Ukraine, a positive result was found. Especially in those regions where the issue of informatization was solved by government officials, using analytical and expert technologies.

Today, a comprehensive information system of information and analytical monitoring has been created in the region, where the key stage is management decisions.

The stages of formation of the information environment are the setting of tasks, DBMS, modern information processing, the latest modes of information dissemination.

The growth of the information infrastructure has affected the development of new information and analytical resources, the introduction of new network technologies. This leads to the emergence of analysts and the introduction of programs to design networks of analytical and expert services, which will improve the structured integrated management of the region. At the present stage of social development, managers with progressive thinking with a positive experience of market economy began to appear [1,9]. All this is included in the detailed programs for the creation of analytical services and training of correspondent staff.

Problems of regional management in the process of making management decisions are duplication of da- 
tabases, lack of control and analysis of all information resources in the region.

One of the main areas of analytical activity is examination, which provides such functions as preparation of reports, analytical reviews. As well as reference functions, which include the preparation and conduct of negotiations, expert or reference services, work with the public, information and analytical monitoring $[1,9,10]$.

In the management sphere, the basic principles of design are widespread, namely the principle of "golden section", the principle of "eternal learning", the principle of friendship, the principle of "working for authority", the principle of psychological stability and confidence $[1,10]$.

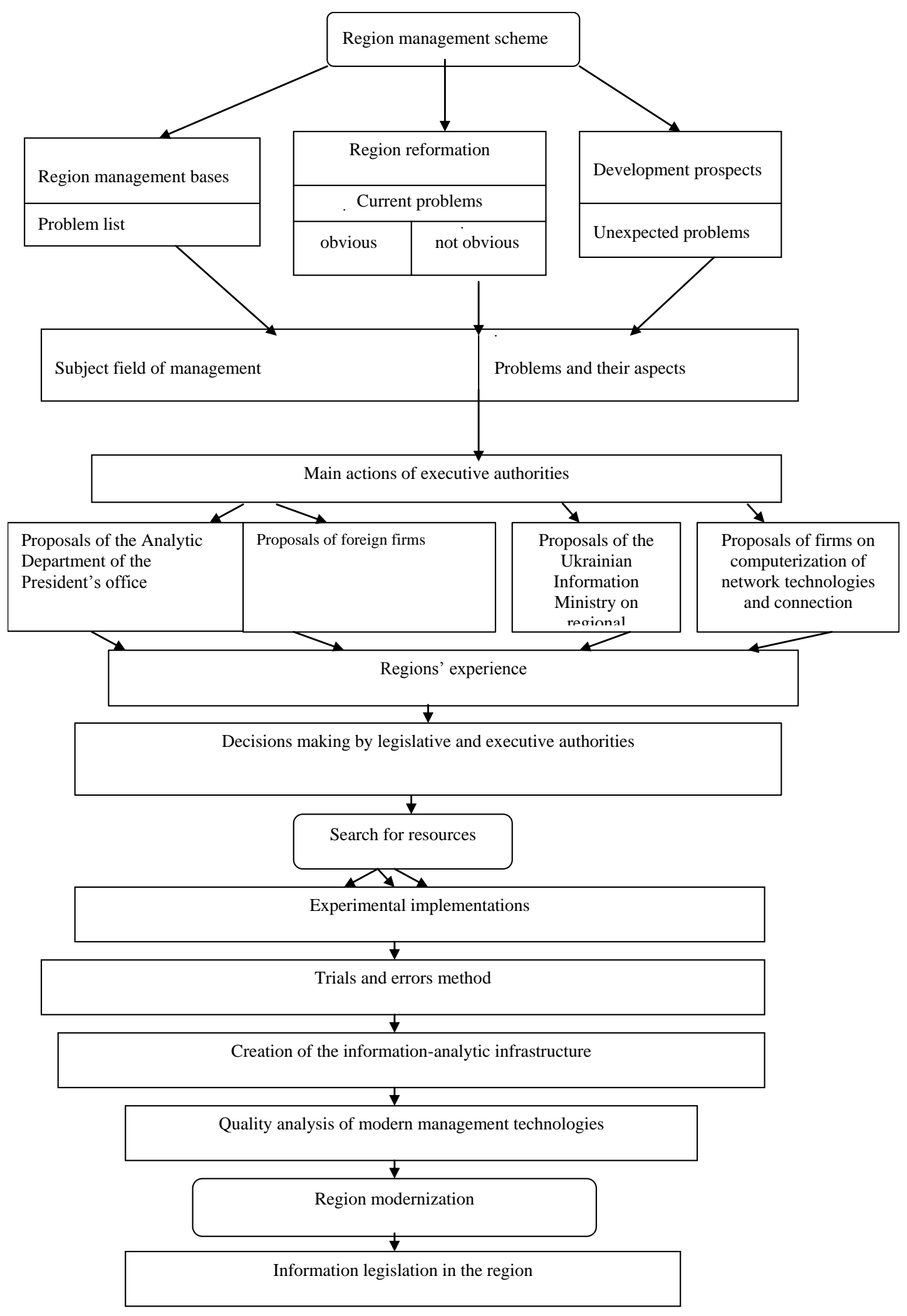

Fig. 1. Region management scheme [1]. 


\section{Conclusions}

1. The strategies of information-analytical research in management are substantiated, which will allow to systematize information-analytical activity, will improve planning, organization and coordination of managerial decision-making.

2. The relevance of the use of informationanalytical research is determined, which will help to form a significant information capital for making relevant management decisions at all hierarchical levels of management.
3. The main aspects of analytics for making systemic decisions in the management sphere are analyzed, because it is information, obtained from verified, correlated facts, which are presented in such a way as to contribute to the solution of a specific management task.

4. Features of completeness and reliability of information for making relevant management decisions in information and analytical activity, which systematizes primarily the field of management, which is rapidly evolving and based on the information, obtained by analytical methods for the practical activities of management, are elucidated.

\section{References}

1. Silkova, H. V. (1998). Osnovy informatsiino-analitychnykh doslidzhen. Rivne: RIS KSU, 50.

2. Zakharova, I. V., Filipova, L. Ya. (2013). Osnovy informatsiino-analitychnoi diialnosti. Kyiv: Tsentr uchbovoi literatury, 336.

3. Peleshchyshyn. A., Yakovyna. V., Dobrovolska, V. (2019). Cultural Institution Information Pattern Formation within Social Media Communities. Proceedings of the 1st International Workshop on Control, Optimisation and Analytical Processing of Social Networks (COAPSN-2019). Lviv, 42-53. Available at: http://ceur-ws.org/Vol-2392/paper4.pdf

4. Kobieliev, O. M. (2013). Informatsiino-analitychna diialnist bibliotek Ukrainy: teoretyko-metodolohichni zasady rozvytku. Kharkiv, 192.

5. Andersen, T., Schrøder, P. (2010). Strategic Risk Management Practice: How to Deal Effectively with Major Corporate Exposures. Cambridge: Cambridge University Press. doi: http://doi.org/10.1017/cbo9780511816017

6. Bedford, T., Cooke, R. (2001). Probabilistic Risk Analysis : Foundations and Methods. Cambridge: Cambridge University Press. doi: http://doi.org/10.1017/cbo9780511813597

7. Griffin, A. (2007). New Strategies for Reputation Management: Gaining Control of Issues, Crises \& Corporate Social Responsibility. London: Kogan Page Publishers.

8. Danyliuk, O.A. (2017). Matematychnyi praktykum v seredovyshchi MATHCAD. Prosti obchyslennia i redahuvannia. Ternopil: TNPU, 30

9. Danyliuk, O. A. (2019). Kompiuterno analitychna diialnist. Ternopil: TNPU, 148.

10. Petryshyn, L. Y. (2018). Strategies for modelling of creativity of social pedagogues in the educational process. Naukovyi visnyk Uzhhorodskoho natsionalnoho universytetu. Seriia: Pedahohika. Sotsialna robota. Uzhhorod, 1 (42), $173-178$.

Received date 18.05.2021

Accepted date 22.06.2021

Published date 30.07.2021

Olha Danylyuk, PhD, Associate Professor, Department of Computer Technologies, Ternopil Volodymyr Hnatiuk National Pedagogical University, Krivonosa str., 2, Ternopil, Ukraine, 46011

Lyudmyla Petryshyn, Doctor of Pedagogical Sciences, Professor, Department of Social Work, Special Education and Management of Socio-Cultural activities, Ternopil Volodymyr Hnatiuk National Pedagogical University, Krivonosa str., 2, Ternopil, Ukraine, 46011

*Corresponding author: Olha Danylyuk, e-mail: daniluk7122@gmail.com 